\title{
Luxury, Luxury Brand and Luxury Market in India: From Class Consumers to Closet Consumers
}

\author{
Neha Bothra* \\ Assistant Professor** \\ Ph.D. Candidate, Department of Financial Studies, University of Delhi, Delhi
}

\begin{abstract}
The luxury concept has throughout history played an important role in social life by being a clear indicator of knowledge and social class which has not changed at present but only becoming catchier. Today, the demand for luxury brands is ever increasing and brand offering is continuously on the rise. The luxury market is expanding rapidly in India on the back of economic deregulation, fast GDP growth, wealth (re)generation, increasing per capita consumption, and a growing young working population. Wealthy Indians represent a source of enormous potential for global luxury brands. India would have more than double the number of HNIs to 403,000 by 2015 from 153,000 in 2010 and communication media have put luxury in the public eye. India's luxury market is expected to reach $\$ 14.72$ billion by 2015 from an estimated $\$ 8.21$ billion this year, with about $30 \%$ of the customers coming from smaller cities, according to a recent report by ASSOCHAM and Yes Bank. This descriptive and conceptual paper looks at the ingredients of a luxury brand and how to market them. The paper goes on to discuss several luxury brands in India, meaning of luxury for Indian and behaviour of closet consumers This paper also analyses the Luxury market Scenario in India, and explains how the Luxury Market is yet to achieve its boom.
\end{abstract}

Keywords: INDIA, LUXURY, LUXURY BRANDS, CLOSET CONSUMERS, SOCIO-CULTURAL VALUES.

\section{Introduction: Beauty Of Human Race}

India has always had a rich tradition of luxury. Addressed as the Golden Bird, India has experienced Maharajas and Nawabs who had refined tastes and were connoisseurs of luxury. Describing luxury as "balance, harmony and beauty of human race", the luxury market in India garners huge attention and is sometimes seen as a sign of India having "arrived". The talk is about the new-found spending power of the Indian consumer, Indian luxury brands and flashy consumption culture. India is a huge potential market for luxury, yet players face serious growth challenges and companies make money with great effort. The luxury market has grown at 23 per cent since 2006. The luxury products market (apparel, watches, jewellery, spirits, and electronics) has grown at 30 per cent, reaching a market size of $\$ 2$ billion. The luxury assets market-cars, homes and yachts-have grown at 25 per cent, and have a market size of $\$ 2.8$ billion. In the last year, 50 luxury outlets (product stores and car showrooms) have been added to the 200 that existed, a 25 per cent growth in footprint. The market, at 1 per cent of the global luxury market, is still small; the luxury products market in China is $\$ 12-13$ billion and Europe is 40 per cent of the global market. Key growth drivers are the 150,000-plus HNIs (high net worth individuals) with a net worth of $\$ 600$ billion-3.1 million households earning more than Rs.10 lakh in the top 10 cities (Mumbai, Delhi/NCR, Bangalore, Kolkata, Pune, Chandigarh, Hyderabad, Ludhiana, Chennai and Ahmedabad). All is not well though. Import duties are high (20-150 per cent), foreign investment in luxury retail comes with strings attached-100 per cent FDI in both single and multi-brand retail requires 30 per cent of local sourcing, a clause which luxury players find difficult to comply with-and there just isn't enough quality retail real estate available. These issues have been known since the outset. Industry growth of 23 per cent, while good, is expected, given the small base. Many larger consumer industries do grow in mid-double digits. In the face of all of these challenges, a few business groups have emerged as consolidators of luxury brands (Hundakari, 2012). CII-IMRB report,2013'The Changing Face of luxury in India' gives an overview of the luxury market today that has witnessed robust growth of $\sim 15 \%$ over the last 3 years and is estimated to have reached $\sim$ USD 7.58 billion in 2012. Luxury products have grown the fastest at $\sim 22 \%$ as compared to luxury services at $\sim 15 \%$ and luxury assets at a much lower $9.4 \%$ - primarily contributed by slow growth in luxury real estate. It is the luxury categories like apparel and accessories, perfumes, fine dining and automotive that has contributed to this growth.

\section{Defining Luxury, Luxury Brands and Literature}

"Luxury is anything that is desirable and more than necessary and ordinary."

Defining luxury has been always been very subjective. Scholars explain it dynamically with changing times and scenarios. "Luxury is any expenditure that goes beyond the necessary", as Werner Sombart begins his essay on the concept and nature of luxury (Sombart, 1992). While the notion that luxury is essentially surplus is a 
common one, it has been contested in scholarly debates. Two centuries before Sombart, Mandeville had tackled the definition of luxury against necessity in "The Fable of The Bees", his controversial defence of luxury against prevailing moral views of the age. He proposed that in a strict sense, luxury is "every thing $[\ldots]$ that is not immediately necessary to make Man subsist" (Mandeville, 1932). While Mandeville can be accused of deliberately complicating or even confuse the concept of luxury in challenging what he saw as prejudiced views, his arguments can be said to foreshadow contemporary critique naturalistic or essentialist notions of need and utility (Baudrillard 1993, Appadurai 1986). He lists five characteristics of luxury (Appadurai, 1986), (1) Restriction to elites by law or price (2) Complexity of acquisition - which may or may not reflect real "scarcity" (3) Semiotic virtuosity (4)Codes for "appropriate" consumption demanding specialized knowledge 5) High degree of linkage of their consumption to body, person and personality Such a position assumes human needs, at least primary needs, to be fundamental instincts or reflexes and hence ahistorical and acultural (Mortelmans, 2005).

The adequate definition of luxury is long overdue for researchers and marketers. Since the 1980s, the luxury market has grown at about ten percent per year, a much higher rate than the world economy, making the luxury industry a relevant economic factor (McKinsey 2011). Estimates of the size of the market for traditional luxury categories including fashion, jewellery and tableware range from about 150 billion $€$ to 200 billion $€$ in 2010 (Bain \& Company 2011). Considering not only traditional luxury categories, but also cars and services such as hotels and travel, the global luxury market is estimated to approach 1 trillion $€$. Despite the current economic uncertainties, Bain \& Company (2011) forecast the luxury market to grow in the next few years by about five to six percent p.a. worldwide and by even more than ten percent p.a. in Asia. High growth rates and the prospect of high margins attract numerous new players into the luxury market (Meffert \& Lasslop 2003). This includes mass-market manufactures aiming to upgrade their products and brands into the luxury segment, as well as a wave of new luxury ventures (Heine 2011). Before they can enter the luxury market, however, these companies need to know what actually constitutes a luxury product or brand.

We have ample literature on luxury.

The recent book on luxe market written by Glyn Atwal, Soumya Jain (2012) "The Luxury Market in India: Maharajas to Masses" provides strategies to guide brands entering this high-potential market and capture the luxury rupee. "The Cult of the Luxury Brand: Inside Asia's Love Affair with Luxury" by Radha Chadha and Paul Husband explore how and why an amazing "luxeplosion" is rocking Asia, sweeping up not just the glitzy upper crust, but secretaries toting their Burberry bags, junior executives sporting Rolex watches, and university students in Ferragamo shoes. Hong Kong boasts more Gucci and Hermes stores than New York or Paris. India, the new kid on the luxury block, has three-month waiting lists for hot items, while in Tokyo, the epicenter of the cult, $94 \%$ of women in their 20s own a Louis Vuitton bag. The cult of the luxury brand is so powerful that Asian consumers account for as much as half of the $\$ 80$ billion global luxe industry. Radha Chadha and Paul Husband explain the paradox of simultaneously pumping up your product's status while pumping it out to the masses.

Other equally important text available on the topic are "Luxury Retail Management: How the World's Top Brands Provide Quality Product and Service Support" by Michel Chevalier, Michel Gutsatz (2012), Luxury Strategy in Action by Jonas Hoffmann, Ivan Coste-Maniere (2011), Jean-Noel Kapferer, Vincent Bastien (2009) in the book "The luxury strategy: break the rules of marketing to build luxury brands" highlights that luxury is in fashion. The Luxury Strategy unveils how in any market, including B to B, a company can learn from luxury strategies to differentiate itself profitably. An important book authored by Robin Lent, Genevieve Tour (2009) titled "Selling Luxury: Connect with Affluent Customers, Create Unique Experiences through Impeccable Service, and Close the Sale". Michael Boroian, Alix de Poix (2009) in their book "India by Design: The Pursuit of Luxury and Fashion" intend to say that a rational view of the growing Global Luxury and Fashion Brands market in India. Scholars like Michel Chevalier, Gerald Mazzalovo (2008), Uche Okonkwo (2007), Pamela Danziger (2005) gave luxury marketing and strategies that marketers can implement to build their luxury brands.

\section{Objectives of the Paper}

This paper covers the following objectives:

- To determine the concept of luxury for Indians.

- To determine the role of closet consumers in Indian luxury market.

- To study the factors liable for increase in luxury brand purchase in India.

- To explain how the Luxury Market is on the verge to achieve its boom.

\section{Research Method}

The vicinity of study is of conceptual nature making use of secondary data. The key objective of this research is to connect the gap between traditional Indian luxury and the Indian Luxury retail market. The paper is of descriptive nature. It is to provide answers to the questions of who, what, when, where, and how associated 
with the research problem of the luxus market; a descriptive study cannot conclusively ascertain answers to why. Descriptive research is used to obtain information concerning the current status of the phenomena and to describe "what exists" with respect to variables or conditions in a situation. This study will rely primarily on deductive reasoning. The paper is oriented towards describing the concept of luxury; the luxury has been displaced by the luxury brands. The relevance of luxe brands in the luxury market in contemporary scenario is to be discussed in detail. The entire paper is to deal with the market in Indian perspective.

The significant data is collected from various sources: Bulletins of Reserve Bank of India, publications from Ministry of Commerce(Govt. of India), The Changing Face of luxury in India 2013(CII-IMRB report), India Boarding 2013(TCS Report), India Luxury Review 2011(CII-AT Kearney Report), World Development Indicators Database 2012, World Wealth Report 2013(Capgemini and RBC Wealth Management), newspapers (Financial Express, The Business Line, The Economic Times etc) has also been included. The data collected from sources is evaluated to find out the inferences for further suggestions and recommendations.

\section{Luxury Market in India: A Growth Story}

In India, back in 70's and 80's if any anyone used to own a telephone or a car then they were seen as "well-heeled"(rich man) and if by chance they owned a gas connection with a refrigerator they were considered as "kings"(very wealthy). Indians in those days didn't know much about the luxury and that is why that age was considered as the age of incorruptibility or innocence. Those who went to other countries and came back with branded and designer labelled stuffs and the brands limited maximum up to brands like Gucci and Christian Dior. Rich Indians are found to be more attracted towards these global luxury goods and services. In upcoming years the growth of this luxury market will be explosive. A Paris-based website has already broadcasted a research done on India's luxury talent. National Skill Development Corporation, a firm that accelerate economic development in India and other emerging economies predicts that by the end of 2022 around 1.76 million people will be required to stock all the luxury brands and services.

French ambassador to India Jerome Bonnafont told in the 2008 luxury summit, "because of lavish Indian weddings, media advertisements, maharajas and Bollywood stars, I feel the art of luxury is alive in India. With the democratization of luxury in the 1990s (Kapferer and Bastien, 2009) which broke out with the conglomeration of luxury initiated by Bernard Arnault, the construct of several luxury houses has changed to more organized corporate firms and their reach has crossed borders. For many international luxury brands, having a presence in India has been little more than a branding exercise. "For international luxury brands, the market is still impervious," said Armando Branchini, the head of Altagamma, an Italian luxury trade group. People like Mr. Branchini have long been lobbying Indian policymakers to make it easier for global luxury brands to expand - and make a profit - in India. Tariff and non-tariff barriers, they say, are preventing the sector from booming here the way it has in China.

India being the second-fastest growing economy is believed to be one of the most sought after market by the luxury brands. Designers around the world have been taking inspiration from India's rich fashion history with bright Bollywood colours, exotic saris, elegant embroidery and stunning jewellery. The growing number of Indians in the billionaire's club coupled with a evident rise of the urban elite class has seen many international luxury giants queue up to woo the Indian customer who has a peculiar culture of "status". A big brand like Chanel launched its 2012 Paris-Bombay Collection in December of 2011 and Hermès put out a limited-edition line of saris, which instantly drew the world's attention to the glamour and glitz of India. Luxury brands have thoroughly considered the significance of understanding India's spending power and rituals as there are definite times when luxury spending isn't welcome, but other times like weddings and festivals which are prime times for offering high-end, luxury items.

The luxury market in India is gaining increasing visibility with each passing year. While the discourse generated by this sector is disproportionately high compared to the size of the market today, it does indicate that most global luxury brands recognize the potential of the Indian luxury market. With the high growth rates of the Indian market compared to the counterparts and even the mature economies, it is only likely that interest in the Indian luxury market will increase in the days ahead. Although today, the traditional wealthy are more dominant. But 10 years hence, we will see that the growth in the number of high net worth individuals will come from young professionals as well as the first-generation entrepreneurs, who will be key consumers of luxury brands. The luxury market in India experienced robust growth of $20 \%$ over the past year and is estimated to have reached USD 5.75 billion in 2010. Luxury products have led the way in the market, growing much faster than projections. Services have also performed well, with most categories exceeding expectations. Luxury assets like cars have continued on their strong growth path, surpassing forecasts for the fourth year in a row. However, the overall growth rate in assets was hampered by a slowdown in luxury real estate. Of particular interest to note is the growth rates enjoyed by market leaders - high double digits led by a combination of same store sales and footprint expansion. Luxury has gone beyond Delhi, Mumbai and Bangalore to Chennai, Hyderabad and Pune, which collectively now have over 30 stores in apparel, accessories, watches and personal care. Similarly North 
Mumbai and Gurgaon are two new distinct catchments that have emerged (CII-AT Kearney India luxury review, 2011).

Players continue to move cautiously in the luxury market, there is an increasing sense of buoyancy and optimism amongst the industry leaders about the future potential of the Indian luxury market. While companies realize that India will not be an easy country to play in, it is definitely on the radar of most players as a longterm growth market. Our projections for 2015 of an expected market size of USD 14.72 billion (USD 5.38 billion products, USD 1.45 billion services and USD 7.9 billion assets) remain unchanged.

The luxury market in India is interestingly poised today. Market growth over the past year was higher than expectations and this strong upward trajectory is likely to continue over the year ahead. Optimism amongst luxury players seems increasing, driven by positive consumer sentiment. Consumers are evolving much faster than predicted, and are quickly catching up with global trends. While several challenges exist, luxury players are now shifting focus from fighting against these constraints to innovating within their confines. In this environment, luxury players are moving forward with a mix of hope and caution. A handful of players that have taken bold, market making moves are beginning to reap early rewards. While there are no easy "silver bullet" solutions, we see a few emerging themes on how to grow and operate profitably in the Indian luxury market. The two key factors we see that have not helped luxury brands realize the potential of the market is firstly the extent of investments made by luxury brands both in terms of creating the environment and in terms of the investments they have made in awareness creation and secondly getting the right products that address the market with the right price points (CII-AT Kearney India luxury review, 2011).

\section{Luxury Brands: Quality, Status and Appeal}

Luxury brands have always fascinated consumers due to their quality, status and appeal. At the base level, luxury brands are known to deliver superior experience at two levels - first, at a product level and second, at an experiential level. At a product level it satisfies the functional and utilitarian characteristic like craftsmanship, precision, materials, high quality, unique design, extraordinary product capabilities, technology and innovation. And at experiential level they appeal to the emotions of the consumers. For example: Rolex stands of symbol of heroic achievement and Tiffany is a symbol of love and beauty. Surprisingly, lost of luxury brands have a rich pedigree and extraordinary history. A consumer purchasing a Gucci or Prada product is no doubt influenced by brand's rich lineage, heritage and the years of mastery. The 2013 BrandZ Top 100, a ranking of the most valuable global brands compiled by research firm MillwardBrown, ranked Louis Vuitton, Hermes and Gucci were the top three global luxury brands of 2013. The survey said luxury brands had become more "accessible, collaborative and experimental".

10. Coach,Brand (Value: $\$ 3,276 \mathrm{mn}$ ), Handbag firm Coach owed its position at number 10 on the list to its presence in China where it added 30 stores by the end of 2012, taking its total there to 69 . The survey said it was among the firms making extensive use of social media and the Internet, "emailing over 1.2 billion messages to selected customers".

9. Fendi,Brand (Value: $\$ 3,636 \mathrm{mn}$ ) As one of Italy's most respected names in fashion, Fendi is known for staying a step ahead of emerging trends.

8. Burberry,Brand (Value: \$4,194 mn) Burberry Group plc is a British luxury fashion house, distributing clothing and fashion accessories and licensing fragrances. Angela Ahrendts, CEO of Burberry, has been named as the first woman to make it to the top of Britain's executive pay league. Ahrendts has been credited with 'dechavving' Burberry and turning it into one of the world's most powerful luxury fashion houses. Her aggressive approach towards social media and innovative promotional concepts is well recognized to escalate the oncetraditional brand to the limelight.

7. Cartier,Brand (Value: $\$ 6,377 \mathrm{mn}$ ) World renowned in jewelry and prestige watchmaking, Cartier has combined expertise and excellence since 1847. Throughout a history spanning well over a century, the French jeweler Cartier has retained an inimitable style, nurtured by its heritage and occasionally inflected by the tastes of some of the most extraordinary personalities of its time.

6. Chanel,Brand (Value: $\$ 7,075 \mathrm{mn}$ ) Chanel is a privately held company owned by Alain and Gerard Wertheimer, grandsons of Pierre Wertheimer. The company makes clothes, fragrances, handbags and watches. The brand is most famous for its "little black dress", the Chanel No. 5 perfume and the Chanel Suit.

5. Rolex,Brand (Value: $\$ 7,941 \mathrm{mn}$ ) Rolex is the renowned name in the world of luxury wristwatches. It is headquartered in Geneva, Switzerland, but relies on 4,000 watchmakers in more than 100 countries. It created the world's first waterproof watch in 1926. Some of the world's most famous athletes pitch Rolex watches including: Tiger Woods, Phil Mickelson, Roger Federer and Lindsey Vonn.

4. Prada,Brand (Value: $\$ 9,454 \mathrm{mn}$ ) The Prada brand was created in 1913 by Mr. Mario Prada and has since become one of the most prestigious and widely-recognized brands in the fashion and luxury goods industries. In 2012 , the luxury retailer's brand value skyrocketed $63 \%$, bringing it to $\$ 9.5$ billion, in the BrandZ calculation. That makes Prada the fourth most valuable luxury brand in the world, but the number one riser in any category 
3. Gucci,Brand (Value: $\$ 12,735 \mathrm{mn}$ ) Having risen from $\$ 8,602 \mathrm{mn}$ in 2012 , a 48 per cent jump makes Gucci the second fastest growing brand on this list.

2. Hermès,Brand (Value: $\$ 19,129 \mathrm{mn}$ ) Hermes is one of the grandest houses in the lexicon of luxury goods. Established in 1837 by Thierry Hermes as a fine harness-making business and today world-renowned for its handcrafted, exceptionally desirable (and expensive) leather goods, most notably its Kelly and Birkin handbags. The company has also become a major player in ready-to-wear fashion.

1. Louis Vuitton,Brand (Value: $\$ 22,719 \mathrm{mn}$ ) Louis Vuitton's continued success can be attributed to consistently upholding its core values and remaining loyal to its travel-centric heritage. Louis Vuitton has significantly improved its digital presence - from charting its history on Facebook to launching an app that enables customers to share travel experiences. The brand remains committed to engaging new markets, making it the top gift brand for the Chinese luxury consumer this year. The brand also made its first foray into fragrance in decades with the announced launch of a signature scent by legendary perfumer Jacques Cavallier-Belletrud (BrandZ MillwardBrown report, 2013).

\section{HNIs and Closet Consumers: Different Approaches}

"Closet Consumers", typically are the people who have not been born wealthy and luxury is not a way of life to them yet, they are just experimenting with luxury. Some researchers classify these individuals as "new age high net worth individuals," who are more discriminating about luxury items. While India accounts for less than 2 percent of the global luxury market, it is interesting to watch new wealth emerging, particularly since many of these individuals still have a "middle class mindset." Closet Consumers "won't pick up a Louis Vuitton [bag] because it's Louis Vuitton. They examine it and give a glance to its worth."The new Indian luxury buyer is more aware of brands. While he values and buys international luxury brand offerings, he also appreciates his Indian roots and culture. Perhaps that value-minded outlook will put Indian consumers on par with their Asian counterparts who are increasingly moving away from brand and logo-based luxury items, such as handbags printed with Louis Vuitton's signature monogram or Burberry's quiet checked. But that doesn't mean that the sector's most iconic brands aren't in demand. More luxury-only malls are opening in India, as major destination DLF Emporio mall has over 20 luxury brands waiting to gain space in the shopping complex in New Delhi. And the key to fetch business from young, newly-wealthy buyers is personalization and service. Considering to not portray egotism, retailers and personnel go out of their way to track consumer preferences and tailor shopping experience in order to make first-time luxury customers feel comfortable - a important aspect for a people with "middle-class mindset." But India has far to go before it can begin to compare its offerings and service with markets like China, whose $\$ 25$ billion luxury market dwarfs India's $\$ 6$ billion one. Perhaps the biggest challenge facing luxury brands in the country is not the lack of deep-pocketed consumers but India's complicated and undeveloped infrastructure. But until improvements are made, brands like Dior can be satisfied with selling premium-priced belts, wallets and watches. Surely, the couture clothing won't be far behind (CII-IMRB report, The Changing Face of luxury in India, 2013).

Burberry sells dresses at Rs 24,000 next to those with a Rs 1 lakh price tag, and a diamond ring from a high-end jewellery retailer is suddenly just a bit more within reach, it's clear there's a shift taking place in the luxury business in India. A new Chanel store opening at Delhi's Select City Walk mall is a sign, that luxury brands are willing to compromise in terms of price points and positioning to persuade the new rich emerging from India's middle class. Some are doing so to target new consumers and push sales, while others are looking for options other than expensive retail locations in five-star hotels and "luxury" malls. And although Select City Walk is a tonier shopping destination than most in the National Capital Region (NCR), it's still a regular mall. A large number of consumers in India have to be lured into experiencing the brand. The world's biggest champagne house, Moet Hennessy, has launched its first "made in India" sparkling wine, priced at Rs 1,200 and Rs 1,400 , as it seeks to capture a young, urban and increasingly sophisticated market of drinkers on the subcontinent. The company has been selling imported brands such as Moet \& Chandon and Dom Perignon (priced around Rs 5,800 and Rs 20,000, respectively) for years, but the new launch is aimed at a vast population of young Indians who aspire to luxury brands, but don't necessarily have the budget.

There is a fundamental difference between India and other developed markets such as Europe and the US in terms of consumer profile and demographics. About two-thirds of India's population is below 30 years in age, which is a challenge for most brands as these are aspirational consumers, but may not have the money to buy. Apart from this, rentals in hotels and pure luxury malls are phenomenally high, which puts a lot of pressure on commercial viability. "Which is why they don't mind opening a store next to a premium or a mass brand in a mall that sees more footfalls,". Even in terms of defining a middle-class consumer on the basis of income, there is a vast gap between other developed markets and India. Anyone who earns between Rs 2 lakh and Rs 10 lakh qualifies as a middle-class consumer in Delhi NCR, but the US counterpart earns close to $\$ 40,000$ a year. It's important to play the volume game in India if they want to grow the number of stores here the way it's happening in China. The Indian luxury market is expected to post a slight revival and grow about $17 \%$ next 
calendar year even as the industry faces serious growth challenges in the country, says a new report.( (Rathore, 2013)

There are distinct classifications of HNWI. An investor with less than $\$ 1$ million but more than $\$ 100,000$ is considered to be "affluent", or perhaps even "sub-HNWI". The upper end of HNWI is around \$5 million, at which point the client is then referred to as "very HNWI". More than $\$ 50$ million in wealth classifies a person as "ultra HNWI".

\begin{tabular}{|l|l|}
\hline Classification & Wealth (USD) \\
\hline Sub-HNWI / affluent & $100,000-1,000,000$ \\
\hline HNWI & $1,000,000-5,000,000$ \\
\hline Very HNWI & $5,000,000-30,000,000$ \\
\hline Ultra HNWI & $30,000,000$ and above \\
\hline
\end{tabular}

The "World Wealth Report" published by Capgemini has estimated the number and combined investable wealth of high-net-worth individuals as follows, using the US Consumer Price Index (CPI) Inflation Calculator.

\begin{tabular}{|l|l|l|l|}
\hline Year & \multicolumn{1}{|c|}{$\begin{array}{c}\text { Number of HNWIs } \\
\text { (millions) }\end{array}$} & $\begin{array}{c}\text { HNWI } \\
\text { Wealth } \\
\text { (trillions } \\
\text { USD) }\end{array}$ & $\begin{array}{c}\text { In } 2012 \\
\text { USD } \\
\text { (trillions } \\
\text { USD) }\end{array}$ \\
\hline 2005 & 8.3 & 30.8 & 35.9 \\
\hline 2006 & 8.7 & 33.3 & 37.6 \\
\hline 2007 & 9.5 & 37.2 & 40.9 \\
\hline 2008 & 10.1 & 40.7 & 43.1 \\
\hline 2009 & 8.6 & 32.8 & 34.8 \\
\hline 2010 & 10.0 & 39.0 & 40.7 \\
\hline 2011 & 10.9 & 42.7 & 43.2 \\
\hline
\end{tabular}

Table 1

VIII. Indian Luxury Brands: An Undiscovered Destination

Luxury brands who have tapped the potential in the domestic market tend to cross the border towards the new markets. They are approaching EMEs, south East Asian economies, BRICs. Let's discuss about the budding market of India-an undiscovered destination. Louis Vuitton has 35 stores in China against three in India. Also, the Indian buyer is still traditional in their preferences (as seen in jewellery and clothing), is price conscious and less brand aware, even when there are more options present in the country than there has ever been. Moreover, the market is younger (luxury re-entered India only five years ago) and China has none of the structural barriers (foreign investment and duties). In land of golden bird, import duties are high (20-150 per cent), foreign investment in luxury retail comes with strings attached-100 per cent FDI in both single and multibrand retail that too requiring 30 per cent of local sourcing, a clause which luxury players find difficult to comply with-and there just isn't enough quality retail real estate available. Still giant players are hopeful on India.

Swiss luxury watch maker Raymond Weil sees India as its top 10 global markets in five years but plans to stay away from entering the country's single brand retail segment because of 'complex' policies. Its whollyowned Raymond Weil India Distribution Pvt Ltd supplies products to retailers in India. (ET, PTI Sep 22, 2013) High-end brand Stefano Ricci is waiting for FIPB nod. In yet another sign that luxury retail is on an upswing in India, Italian high-end brand Stefano Ricci has decided to enter the country with 100 per cent FDI. So far, the company specialising in men's luxury fashion has only 34 stores across Europe, Asia and the US. Its flagship store is in Florence. Stefano Ricci is likely to open its India store either in Mumbai or Delhi once its application is cleared by the Foreign Investment Promotion Board (FIPB). ( Nivedita Mookerji, BS, Nov 25, 2013)

Bulgari is the owner of BVLGARI brand operating with 41 companies in 24 countries. Italian luxury brand Bulgari has approached the department of industrial policy and promotion (DIPP) to set up single-brand retail stores in the country. If allowed, this would mark the firm's second entry into India after it ended its seven-year partnership with Mumbai-based Dia Group's sister concern Lifestyle Tradelinks India in 2011.( FE, Kirtika Suneja, Nov 11 2013)

It's not just business houses that are keen to get the taste of luxe, education institutions also are willing to serve the industry with the skilled workforce. The London Business School is going luxe. On Oct. 22 2013, the school launched its first MBA concentration in luxury management. The partnership with Walpole British 
Luxury, a professional organization for the British luxury industry, LBS students in the program will have access to brand name luxury companies such as Burberry and Alexander McQueen.

Indian Institute of Management, Bangalore announces a three-day executive education program in luxury business. Titled 'Strategic Management of Luxury Business: Managing Luxury Products and Services - from Concept to Consumer', the program is targeted at entrepreneurs and CEOs of new luxury businesses, Profit centre managers of international luxury businesses, designers looking to create luxury brands, managers of luxury franchise businesses, suppliers of products/ services to international luxury businesses, marketing managers of luxury brands, and advertising agency executives of luxury brands.

Out of the 40-plus luxury brands present in the country, Genesis Colors, Reliance Brands, Major Brands and DLF Brands have franchises, distribution agreements or joint ventures with almost 15-20 of them. Like most industries in India, learning from other markets is only partly useful. There is no substitute to staying invested based on a belief in the market fundamentals and ground innovation. Educating the consumer is key; customisation is imperative (sizes, designs, home delivery models) and sharp pricing a sine qua non. Reaching new consumers while retaining the loyalty of existing ones is critical and use of media and creating opportunities for the consumer to experience the product are key factors for success.

Why are there no home grown luxury brands?

India has traditional expertise in textiles, leather, personal care (Ayurveda) and jewellery. Indian fashion designers are truly coming into their own now. For instance, Ritu Kumar, Tarun Tahiliani and Sabyasachi are setting up stores abroad and expanding. Hidesign is an example of a premium leather brand, Forest Essentials is taking Ayurvedic recipes into high-end personal care and Amrut is an Indian single malt which has received rave reviews. In addition, the royal heritage of India provides the perfect platform for highend luxury services-hospitality, fine dining, spas. Taj, Oberoi, ITC have all created a name for themselves internationally.

\section{Interpreting Luxury Statistically}

\section{In 2012, Global HNWI wealth grew $10 \%$, reaching a record-high of $\$ 46.2$ trillion.}
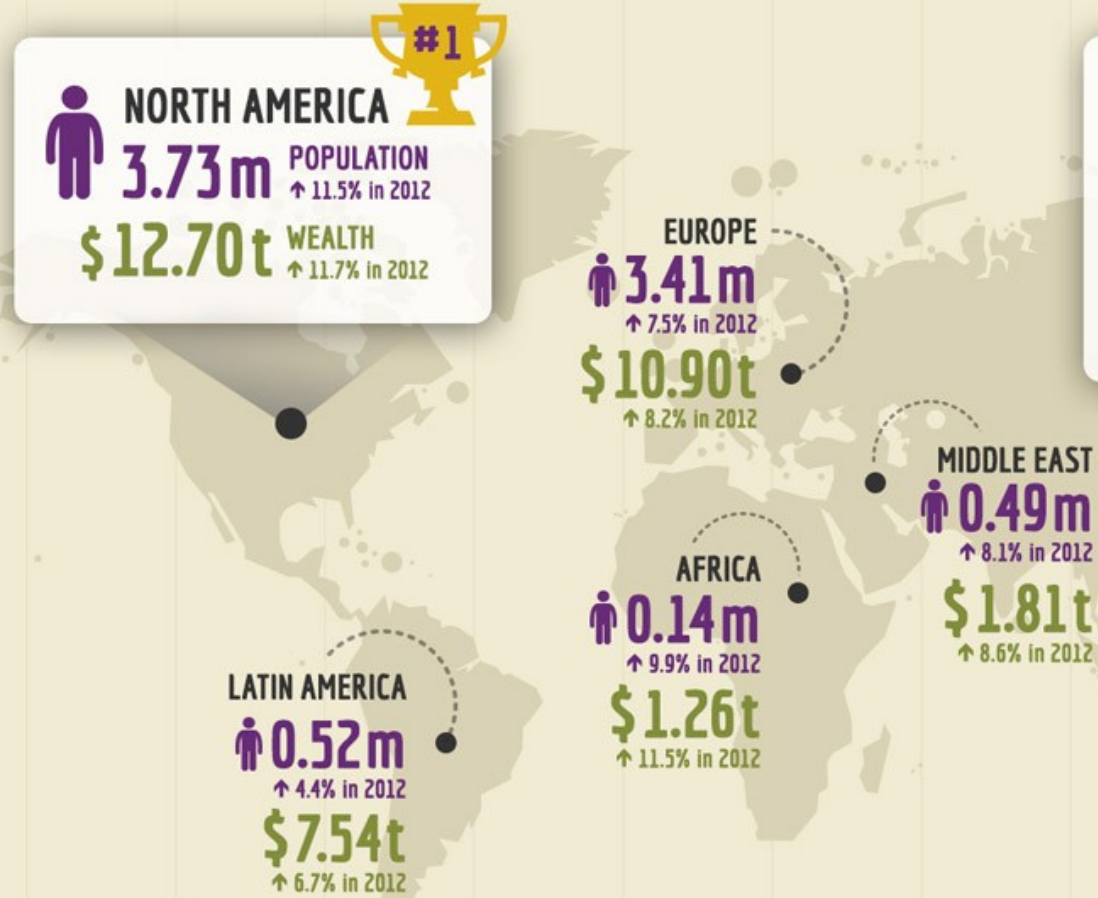

ASIA-PACIFIC

Figure-1

SOURCE: World Wealth Report 2013 from Capgemini and RBC Wealth Management 
I. Geographical Footprint of Luxury Product Brands

\begin{tabular}{|c|c|c|c|c|c|c|c|}
\hline Category & Brand Name & Total Stores & Mumbai & Delhi & Bangalore & Chennai & Hyderabad \\
\hline Accessories & Alfred Dunhill & 3 & 1 & 1 & 1 & 0 & 0 \\
\hline Apparel \& Accessories & Blues Clothing & 8 & 1 & 6 & 0 & 0 & 0 \\
\hline Apparel \& Accessories & Bottega Venetta & 3 & 1 & 1 & 1 & 0 & 0 \\
\hline Appare: I & Brioni & 2 & 1 & 1 & 0 & 0 & 0 \\
\hline Apparel \& Accessories & Burberry & 5 & 1 & 2 & 1 & 0 & 1 \\
\hline Apparel \& Accessories & Canali & 6 & 1 & 2 & 1 & 1 & 1 \\
\hline $\begin{array}{l}\text { Apparel, Accessories } \\
\text { and Personal Care }\end{array}$ & Chanel & 2 & 1 & 1 & 0 & 0 & 0 \\
\hline $\begin{array}{l}\text { Apparel, Accessories } \\
\text { and Personal Care }\end{array}$ & Christian Dior & 3 & 1 & 2 & 0 & 0 & 0 \\
\hline Apparel \& Accessories & Collective & 3 & 1 & 1 & 1 & 0 & 0 \\
\hline Apparel \& Accessories & Diesel & 9 & 2 & 1 & 1 & 1 & 1 \\
\hline Apparel \& Accessories & Ermenegildo Zegna & 4 & 1 & 1 & 1 & 0 & 1 \\
\hline Personal Care & Estee Lauder & 3 & 1 & 1 & 1 & 0 & 0 \\
\hline Apparel \& Accessories & Etro & 3 & 1 & 1 & 1 & 0 & 0 \\
\hline Apparel \& Accessories & Gucci & 3 & 1 & 2 & 0 & 0 & 0 \\
\hline Apparel \& Accessories & Hermes & 3 & 1 & 1 & 0 & 0 & 0 \\
\hline Apparel \& Accessories & Hugo Boss & 3 & 1 & 1 & 1 & 0 & 0 \\
\hline Accessories & Jimmy Choo & 3 & 1 & 1 & 1 & 0 & 0 \\
\hline Apparel \& Accessories & Just Cavali & 2 & 0 & 1 & 0 & 1 & 0 \\
\hline Apparel \& Accessories & Kimaya & 10 & 2 & 4 & 1 & 1 & 0 \\
\hline Personal Care & Lancome & 11 & 1 & 4 & 4 & 1 & 0 \\
\hline Home Décor & Lladro & 11 & 1 & 1 & 2 & 2 & 1 \\
\hline Personal Care & L'Occitane & 8 & 1 & 3 & 2 & 0 & 0 \\
\hline Apparel \& Accessories & Louis Vuitton & 4 & 2 & 1 & 1 & 0 & 0 \\
\hline Watches & Omega & 5 & 2 & 1 & 1 & 1 & 0 \\
\hline Personal Care & Parcos & 2 & 1 & 1 & 0 & 0 & 0 \\
\hline Apparel \& Accessories & Paul and Shark & 4 & 1 & 1 & 0 & 1 & 1 \\
\hline Apparel \& Accessories & Paul Smith & 3 & 0 & 1 & 1 & 1 & 0 \\
\hline Apparel & Salvatore Ferragamo & 4 & 2 & 1 & 1 & 0 & 0 \\
\hline Accessories & Tod's & 3 & 1 & 1 & 1 & 0 & 0 \\
\hline Appare-1 & Tom Ford & 1 & 0 & 1 & 0 & 0 & 0 \\
\hline Accessories & Tumi & 2 & 0 & 0 & 1 & 1 & 0 \\
\hline Accessories & Van Cleef and Arpels & 1 & 1 & 0 & 0 & 0 & 0 \\
\hline \multirow[t]{2}{*}{ Apparel } & Versace & 2 & 1 & 1 & 0 & 0 & 0 \\
\hline & & 131 & 33 & 42 & 26 & 11 & 6 \\
\hline
\end{tabular}

Table-1

\section{Projected growth of luxury market in India}

\section{Growth Projections 2009-15 USD billion}
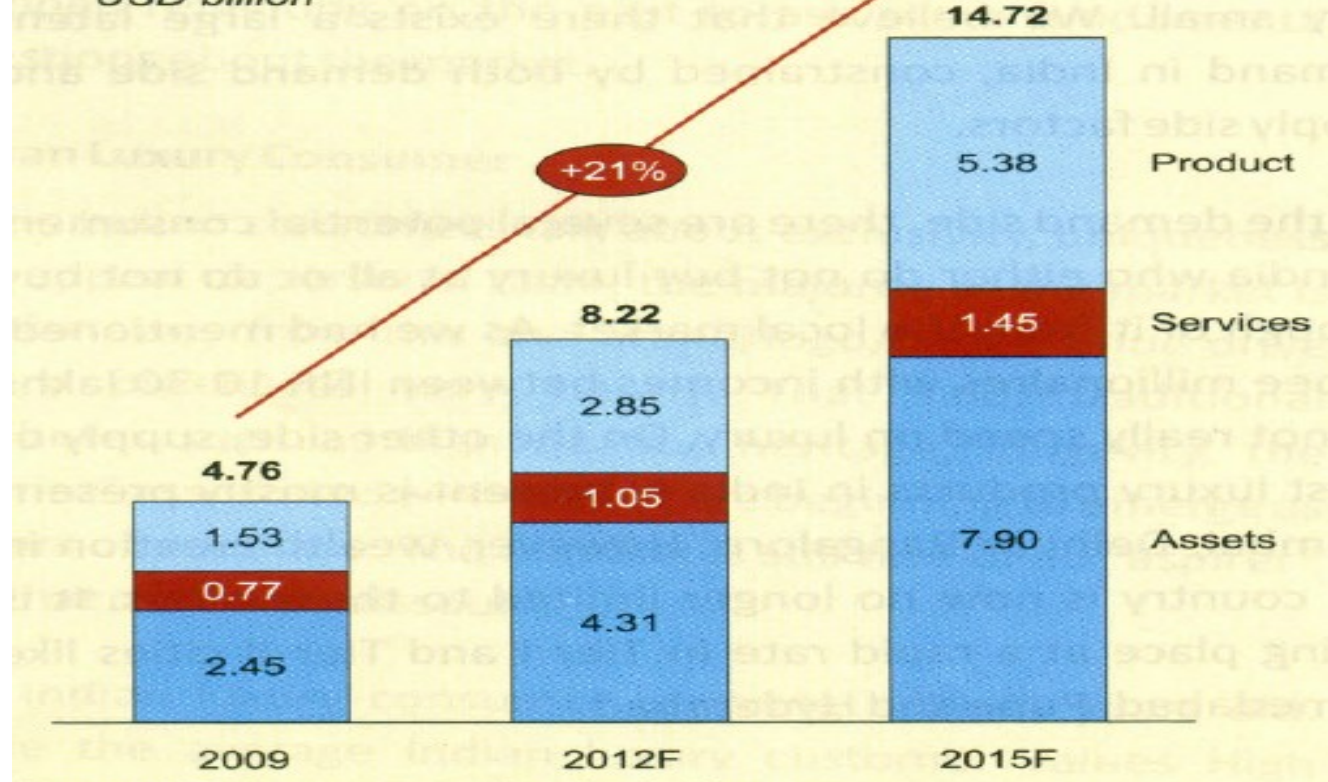

Source: A.T. Keamey research and analysis

Figure-2 


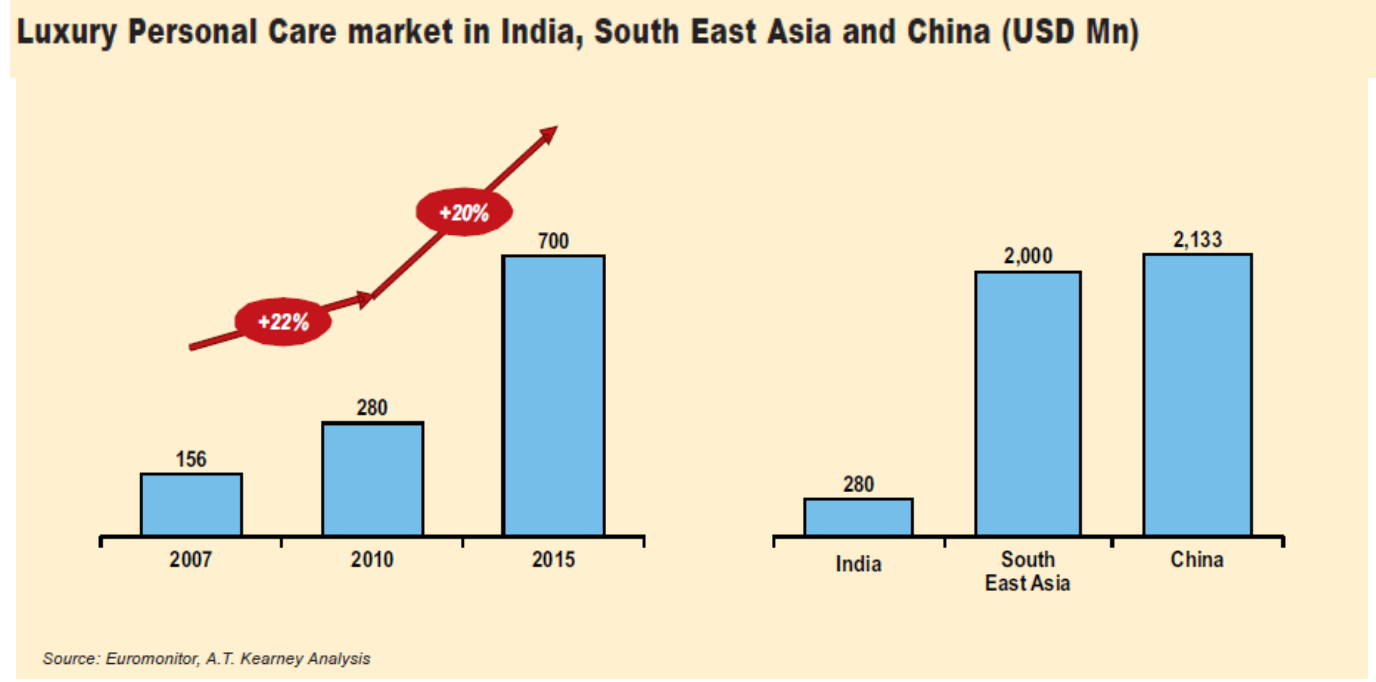

Figure-3

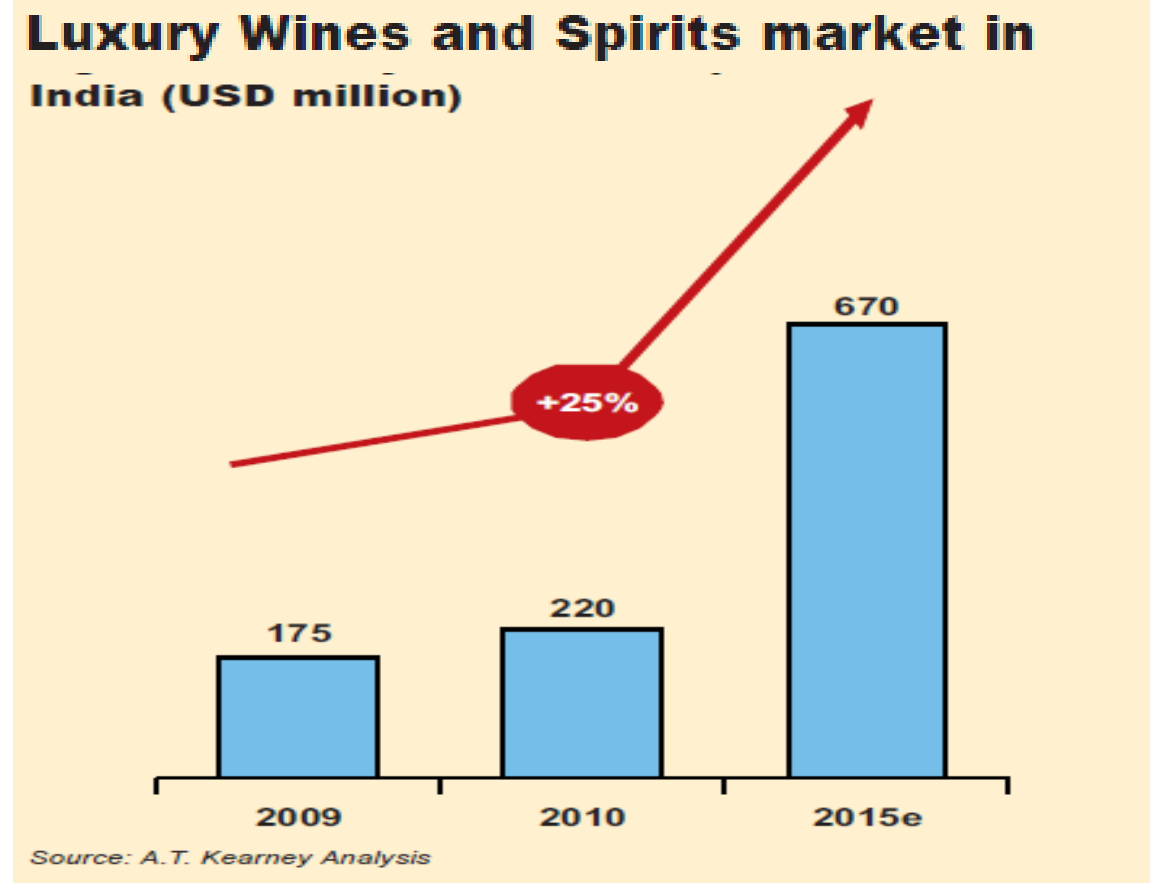

Figure-4

\section{Suggestions and Conclusions: The Road Ahead}

Consumers can "need," "obsessed" and "own" on an item. The simple reason to hunt for the name and spend irrationally is the brand itself. While they value and buy international luxury brand offerings, none can deny the widespread appreciation of Indian roots and culture. From Kashmir to Kannyakumari, ample number of cultures and traditions are in the queue. None of them have uniform definition of luxury. Every royal family had their own craftsman so as to have their status held high. It is almost impossible to think of that consumption pattern today. As far as India is concerned, now we have the emerging closet consumers besides the HNIs to aid the rising demand of sector. Consumers are sharing their preferences through the actions they take. India has been dealing in luxe market since ages, from supply side as well as from demand side and even to add more we do have foreign brands to avoid the consumers travel abroad. The brands and retailers that have mastered their fields are moving on to more innovative approaches such as price, promotion, location-based service, customized services etc. After all, it is more than a product - it is about storytelling.

Primarily, marketers do analyze how a product fits to be a long-term strategy. The product should not be a one-time deal. Then, the product should meet a specific goal. Word of mouth is imperative to luxury brands. A large number of consumers in India are lured into experiencing the brand being influenced by the peers. "The strength of the chain is known by the weakest link." And this is the reason why perfection needs to perfect. It calls for a 360-degree tailored approach to serve the client. Despite its mass-reach, out-of-home 
advertising must be targeted to the affluent audience. Large-scale out-of-home efforts need to tap what affluent consumers are craving: status, exclusivity, high-design and pleasure.

The two most tedious issues regarding the luxury goods are: defining it and advertising it. Affluent consumers can decode messages in a different way than most consumers. The target clientele is extremely differing from the normal good. So every step has to be equally different and cautious. The luxury industry is expected do better in 2013 along with the economy, and affluent customers will be spending more. But high-end consumers are likely to be thinking, "I have worked hard all my life and this is my chance to enjoy the fruits of my labours" and the closet ones are tending to spend in the similar way.

\section{References}

[1] Department Of Industrial Policy \& Promotion, Government of India, 2012

[2] India Boarding, TCS Report, 2013

[3] India Luxury Review, CII-AT Kearney Report, 2011.

[4] Luxury Goods Worldwide Market Study, Bain and Company, 2013.

[5] Ten most valuable global luxury brands, BrandZ MillwardBrown report, 2013.

[6] The Changing Face of luxury in India, CII-IMRB report, 2013.

[7] The India Luxury Summit, ASSOCHAM and Yes Bank, 2012.

[8] Understanding China's Growing Love for Luxury, Shanghai, McKinsey, 2011.

[9] World Wealth Report, Capgemini and RBC Wealth Management, 2013.

[10] Ahya, C., Roots of Recovery. The Economic Times, January21, 2013.

[11] Hundekari, N., India Today, November, 2012.

[12] Rathore, Vijaya, Bankers are the new luxury entrepreneurs in India. The Economics Times, March 26, 2013.

[13] Rathore, Vijaya, Sahara to launch an Indian luxury brand for global market. The Economics Times, May 11, 2013

[14] Srinivas, N.N., India china want soak the rich. It won't work, The Economic Times, March 12, 2013.

[15] Sikarwar, Deepshikha. Government plans to liberalise FDI norms for single-brand retail to attract big bucks. The Economic Times, March 21, 2013.

[16] Atwal, Glyn and Jain, Soumya, The Luxury Market in India: Maharajas to Masses, UK, Palgrave Macmillan, 2012.

[17] Boroian, Michael and Poix, Alix de, India by Design: The Pursuit of Luxury and Fashion, New Jersey, Wiley Publication, 2009.

[18] Chadha, Radha and Husband, Paul, The Cult of Luxury Brand: Inside Asia's love affair with Luxury, London, Nicholas Brealey Publishing, 2006.

[19] Chevalier, Michel and Mazzalovo, Gerald, Luxury Brand Management: A World of Privilege, John Wile, 2008.

[20] Hoffman, Jonas and Maniere, Ivan Coste, Luxury strategy in Action, UK, Palgrave Macmillan, 2011.

[21] Kapferer, Jean-Noel and Bastein, Vincent, The Luxury Strategy: Break the rules of Marketing to build Luxury brands, UK, Kogan, 2009.

[22] Mandeville, B, The Fable of the Bees: Or, Private Vices, Publick Benefits. Sixth edn. London, J. Tonson, 1732.

[23] Okonkwo, Uche, Luxury Fashion Branding: Trends, Tactics, Techniques, UK, Palgrave Macmillan, 2007.

[24] Tsai, S, "Impact of personal orientation on luxury-brand purchase value: an international investigation", International Journal of Market Research, Vol. 47 No.4, 2005, pp.429-54.

* Ms. Neha Bothra did her graduation in Commerce from Lakshmi Bai College and post-graduation in Commerce from Department of Commerce, Delhi School of Economics, University of Delhi. She has worked as an Assistant Professor in the Department of Commerce, Shyam Lal College (Eve.), University of Delhi. Currently, she is a Ph.D candidate in Department of Financial Studies, University of Delhi. She has presented research papers in international and national seminars and conferences organized by Shyam Lal College (Eve.), Kirori Mal College, University of Delhi and ICFAI Business School, Hyderabad. She has also contributed research article in journals and in the book published by Shri Ram College of commerce, University of Delhi. Currently, she is working on "Scope of Luxury Retail Brand in India".

** Taught at Shyam Lal College (Eve.), Department of Commerce, University of Delhi. 